\title{
EVALUATION OF THE EFFICACY OF THE THREE REGIMENS OF VAGINAL MISOPROSTOL IN THE TERMINATION OF FIRST TRIMESTER PREGNANCY- A RANDOMISED CONTROLLED STUDY
}

\author{
Kavitha Paranthaman', Suchindra Ramamoorthy²
}

${ }_{1}^{1}$ Assistant Professor, Department of Obstetrics and Gynaecology, Government Villupuram Medical College, Villupuram, Tamilnadu, India.

${ }^{2}$ Consultant in Reproductive Centre, Milann Fertility Centre, Bengaluru, Karnataka, India.

ABSTRACT
BACKGROUND
An abortion is the removal or expulsion of an embryo or foetus from the uterus, resulting in or caused by its death. Abortion in the
first trimester is safe compared to the second trimester and medical methods are still safer than surgical techniques. Medical
methods are safe, efficient and simple and result usually in complete abortion. Both Misoprostol and Mifepristone have been used
singly in various doses and also in combination dosage schedule. There are many studies for both and each study claims its
schedule to be superior and safer than others.

Aim: This study is done to compare the efficacy, complications and complete abortion rate of three different doses of vaginal misoprostol alone in first trimester MTP.

\section{MATERIALS AND METHODS}

This is a randomised controlled study. During the period 2004 - 2006, three hundred patients who attended the family planning clinic requesting for first trimester termination of pregnancy were selected at random based on the inclusion and exclusion criteria. Out of the three hundred patients, hundred each were assigned randomly to 200 micrograms, 400 micrograms and 600 micrograms group respectively. Patient was asked to empty the bladder and asked to lie down in the dorsal position with hips abducted and knees semiflexed. After cleaning and draping, a Sim's speculum was introduced into the vagina and posterior lip of cervix was caught with vulsellum.

- 200 micrograms of misoprostol were kept in the posterior fornix every 6 hourly for a maximum of four doses.

- 400 micrograms of misoprostol were kept every 8 hourly for a maximum of three doses.

- 600 micrograms were kept every 12 hourly for a maximum of two doses.

Three drops of distilled water were added to the tablet before keeping in the posterior fornix of vagina to facilitate the mucosal abortion. Patient was kept in the ward till the expulsion was complete- whenever necessary, check curettage was done. Complete abortion was confirmed with ultrasound. If no expulsion occurred after 24 hours, it was considered as a failure and other interventions were offered.

\section{RESULTS}

This study conducted at Government Kasturba Gandhi Hospital for Women and Children during the period 2004 - 2006, compares the efficacy of three different regimens of vaginal misoprostol in the first trimester termination of pregnancy. The results were subjected to statistical analysis using ANOVA with post-hoc test. $78 \%$ of the patients were in the age group of $21-30$ years. $82 \%$ of cases were parous women, whereas only $18 \%$ of cases were nulliparous. Above $85 \%$ of the women in this study belonged to class IV/V socio-economic status. Though patients were selected at random, $73 \%$ of patients were $10-12$ weeks pregnant. In this study induction, abortion interval was less with 600 micrograms of misoprostol. The I-A interval was least when the GA was $10-12$ weeks. In this study complete abortion occurred in $41 \%, 52 \%$ and $74 \%$ of cases in 200 micrograms, 400 micrograms and 600 micrograms groups respectively. There is no significant difference in I-A interval between and within the parity by statistical analysis. There is statistically significant difference in complete and incomplete abortion between the three regimens, ( $p=0.01$ and 0.05). Statistically, there is significant difference in the incidence of side effects with the three regimens.

\section{CONCLUSION}

In this study, Induction-Abortion interval is less with $600 \mathrm{ug}$ when compared to $400 \mathrm{ug}$ and $200 \mathrm{ug}$. Induction-Abortion interval in 10 to 12 weeks of gestation observed in this is less. Complete abortion rate was more with $600 \mu \mathrm{g}$ regimen when compared to other two regimens. Incidence of side effects was less with 200 ug. There was almost similar incidence of abdominal/ uterine cramps and excessive bleeding. Medical management of MTP is a boon to low resource countries like India where infrastructural facilities and trained personnel are at a premium. However, there is scope for misuse of this drug which needs to be curtailed and watched. This is a comparatively inexpensive, easy to administer technique which when used by properly trained persons in a setup with facilities for further management as and when required will go a long way in reducing the unwanted interferences by unscrupulous persons.

\section{KEY WORDS}

Abortion, Misoprostol, Pregnancy.

HOW TO CITE THIS ARTICLE: Paranthaman K, Ramamoorthy S. Evaluation of the efficacy of the three regimens of vaginal misoprostol in the termination of first trimester pregnancy- a randomised controlled study. J. Evolution Med. Dent. Sci. 2018;7(26): 3038-3044, DOI: $10.14260 / \mathrm{jemds} / 2018 / 682$ 


\section{BACKGROUND}

An abortion is the removal or expulsion of an embryo or foetus from the uterus, resulting in or caused by its death. From historical times, termination of pregnancy was practiced with or without legal and social sanctions. The practice of induced abortion according to some anthropologists can be traced to ancient times.

Historically, pregnancies were terminated through a number of methods including the administration of abortifacient herbs, the use of sharpened instruments, camel dung, the application of abdominal pressure and other techniques.

Soranus, a second century Greek physician, suggested in his work of Gynaecology that women wishing to abort their pregnancies should engage in violent exercise, energetic jumping, carrying heavy objects and riding animals.

He also prescribed a number of recipes for herbal baths, pessaries and bloodletting, but advised against the use of sharp instruments to induce miscarriage due to the risk of organ perforation.

The ancient Greeks relied upon the herb Silphium, both as a contraceptive and an abortifacient. Such folk remedies, however varied in effectiveness and were not without risks. Tansy and Pennyroyal are two poisonous herbs with serious side effects that have at times been used to terminate pregnancies.

Because of its greater safety nowadays and great impact on population control, abortion has gained tremendous popularity in the last few decades to get rid of undesired pregnancy.

In fact, it is difficult for any country to reduce its population growth without recourse to pregnancy termination. That is why more and more countries are liberalising their abortion laws. 3.1 lakh legal abortions are being performed every year with an abortion rate of 2.3/1000 women. 4.46 million illegal abortions are being performed every year with an abortion rate of 130 to $200 / 1000$ women. In India, the mortality due to criminal abortion is 500/100000.

Unsafe abortions account for 9 percent of maternal deaths in India. Safe abortion services as provided by law should be easily available-

- By well-trained health care providers.

- Regulation of health system.

- Infrastructure including equipment and supplies.

Abortion in the first trimester is safe compared to the second trimester and medical methods are still safer than surgical techniques. Medical methods are safe, efficient and simple and results usually in complete abortion.

Both Misoprostol and Mifepristone have been used singly in various doses and also in combination dosage schedule.1,2,3

'Financial or Other Competing Interest': None.

Submission 28-02-2018, Peer Review 08-06-2018,

Acceptance 14-06-2018, Published 25-06-2018.

Corresponding Author:

Kavitha Paranthaman

No. 4/590, Kamban Nagar,

Opp. to ATRC, East Pondy Road,

Villupuram-605602, Tamilnadu, India.

E-mail: kavitharu77@gmail.com

DOI: $10.14260 /$ jemds $/ 2018 / 682$
There are many studies for both and each study claims its schedule to be superior and safer than others.

This study is done to compare the efficacy, complications and complete abortion rate of three different doses of vaginal misoprostol alone in first trimester MTP.

In this randomised controlled study, three different dose schedules of misoprostol through the same route of application are analysed as to its efficacy in successfully affecting termination in the lowest possible time with no mortality and no or minimal morbidity.

This study conducted at Government Kasturba Gandhi Hospital for Women and Children, Triplicane, Chennai during the period 2004 - 2006 compares the efficacy of three different regimens of vaginal misoprostol 200, 400 and 600 micrograms in first trimester termination of pregnancy.

\section{MATERIALS AND METHODS}

This is a randomised controlled study done during the period of 2004 - 2006.

\section{Study Setting}

This study was conducted at Government Kasturba Gandhi Hospital for Women and Children, Triplicane, Chennai.

Three hundred patients who attended the family planning clinic at Govt. Kasturba Gandhi Hospital, Triplicane requesting for first trimester termination of pregnancy were selected based on the inclusion and exclusion criteria. Sample size was taken as per our convenience. Patients were randomised using computerised randomisation table and were allocated into three groups.

Out of the three hundred patients, hundred each were assigned randomly by lots to 200 micrograms, 400 micrograms and 600 micrograms group respectively according to the Flow Chart.

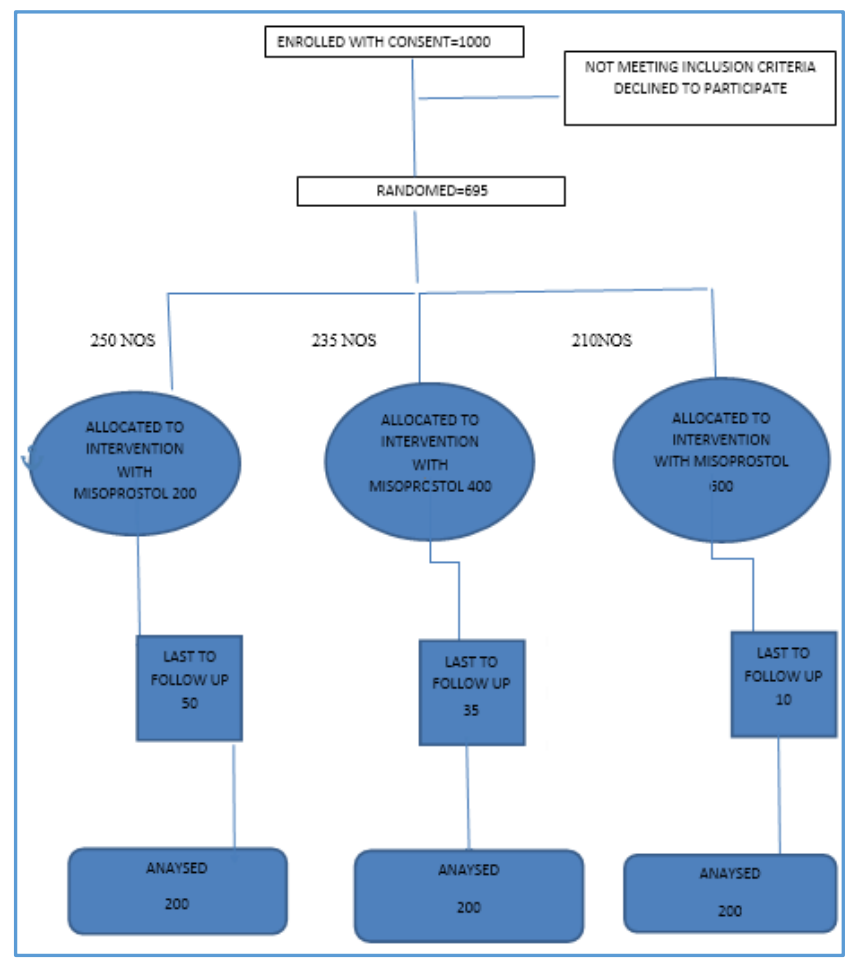




\section{Patient Selection}

\section{Inclusion Criteria}

- Confirmed pregnancy up to 12 weeks.

- $\quad$ Single live intrauterine gestation.

- No previous surgery in the uterus.

- Contraceptive failure.

- No other medical or surgical contraindications for the procedure.

- Medical termination of pregnancy for social and eugenic causes.

\section{Exclusion Criteria}

- Women aged more than 35 years.

- $\quad$ Parity more than G3.

- Heavy smokers (smoking more than 10 cigarettes per day).

- Suspected or proven ectopic pregnancy.

- Inevitable incomplete/Missed abortion.

- Allergy or intolerance to misoprostol.

- Previous history of medical disorders like cardiac disease/ diabetes/ asthma/ epilepsy/ psychiatric disorder.

- Any previous attempts at terminating the present pregnancy.

- Uncontrolled hypertension.

- Severe liver disease/ chronic adrenal failure.

- Anaemia, $\mathrm{Hb}<8 \mathrm{~g} \%$.

\section{Methods}

All these women were thoroughly investigated before performing medical termination of pregnancy. The workup included-

- Details of the patient (Name, Age, Address, Height, Weight).

- Menstrual/ Marital/ Obstetric history.

- Medical/ Surgical history.

- Investigations.

- General examination.

- Examination of vital signs.

- Abdominal and pelvic examination.

- Ultrasound only on indication.

- Counselling.

Such patients who were willing to adhere to the protocol were included for the study. Each group has hundred patients.

All these women were informed about the procedure. An informed consent was obtained from these selected women.

\section{Procedure}

Patient was asked to empty the bladder and asked to lie down in the dorsal position with hips abducted and knees semiflexed.

After cleaning and draping, a Sim's speculum was introduced into the vagina and posterior lip of cervix was caught with vulsellum.

\section{Dosage Schedule}

- 200 micrograms of misoprostol were kept in the posterior fornix every 6 hourly for a maximum of four doses.
- 400 micrograms of misoprostol were kept every 8 hourly, for a maximum of three doses.

- 600 micrograms were kept every 12 hourly for a maximum of two doses.

Three drops of distilled water was added to the tablet before keeping in the posterior fornix of vagina to facilitate the mucosal absorption. Patient was kept in the ward till the expulsion was complete- whenever necessary, check curettage was done. Complete abortion was confirmed with ultrasound.

If no expulsion occurred after 24 hours, it was considered as a failure and other interventions offered. Patients were advised about the symptoms like-

- Nausea/ vomiting and diarrhoea.

- Headache.

- Excessive bleeding.

- Abdominal cramps.

- Dizziness.

- Data management.

- The variables: age, parity, socio-economic status and gestational age.

- Socio-economic status is calculated with the help of income, education and occupation.

\section{Statistical Analysis}

Data was analysed using SPSS 16.0. The qualitative data were expressed as numbers and percentages. The continual variables expressed as mean and standard deviation. Mean and Standard deviation were compared using one-way ANOVA with post hoc test. Chi-square test was used to find difference between the three different groups.

\section{RESULTS}

This study conducted at Government Kasturba Gandhi Hospital for Women and Children during the period 2004 2006 compares the efficacy of three different regimens of vaginal misoprostol in the first trimester termination of pregnancy. (The results were subjected to statistical analysis using ANOVA with post hoc test (Analysis of variance test), other variables were also compared statistically.)

\begin{tabular}{|c|c|c|c|c|c|c|c|}
\hline \multirow{2}{*}{$\begin{array}{c}\text { Age } \\
\text { Group }\end{array}$} & \multicolumn{2}{|c|}{$\begin{array}{c}\text { Misoprostol } \\
200 \mu \mathrm{g}\end{array}$} & \multicolumn{2}{|c|}{$\begin{array}{c}\text { Misoprostol } \\
400 \mu \mathrm{g}\end{array}$} & \multicolumn{2}{|c|}{$\begin{array}{c}\text { Misoprostol } \\
600 \mu \mathrm{g}\end{array}$} & \multirow[t]{2}{*}{$\begin{array}{c}P \\
\text { value }\end{array}$} \\
\hline & $\begin{array}{l}\text { No. of } \\
\text { Cases }\end{array}$ & $\%$ & $\begin{array}{l}\text { No. of } \\
\text { Cases }\end{array}$ & $\%$ & \begin{tabular}{|l|} 
No. of \\
Cases
\end{tabular} & $\%$ & \\
\hline$<20$ & 7 & 7 & 9 & 9 & 7 & 7 & \multirow{4}{*}{-0.954} \\
\hline $21-25$ & 37 & 37 & 38 & 38 & 35 & 35 & \\
\hline $26-30$ & 40 & 40 & 42 & 42 & 43 & 43 & \\
\hline$>30$ & 16 & 16 & 11 & 11 & 15 & 15 & \\
\hline \multicolumn{8}{|c|}{ Table I. Age Distribution } \\
\hline
\end{tabular}

$78 \%$ of the patients were in the age group of 21-30 years. $14 \%$ were in the age group 30 and above.

Only less than $10 \%$ of the patients were in the age group of 16-20 years. 


\begin{tabular}{|c|c|c|c|c|c|c|c|}
\hline \multirow{2}{*}{ Parity } & \multicolumn{2}{|c|}{$\begin{array}{c}\text { Misoprostol } \\
200 \mu \mathrm{g}\end{array}$} & \multicolumn{2}{|c|}{$\begin{array}{c}\text { Misoprostol } \\
400 \mu \mathrm{g}\end{array}$} & \multicolumn{2}{|c|}{$\begin{array}{c}\text { Misoprostol } \\
600 \mu \mathrm{g}\end{array}$} & \multirow[t]{2}{*}{\begin{tabular}{|c|}
$P$ \\
value \\
\end{tabular}} \\
\hline & $\begin{array}{l}\text { No. of } \\
\text { Cases }\end{array}$ & $\%$ & $\begin{array}{l}\text { No. of } \\
\text { Cases }\end{array}$ & $\%$ & $\begin{array}{l}\text { No. of } \\
\text { Cases }\end{array}$ & $\%$ & \\
\hline UMP & 2 & 2 & 1 & 1 & 2 & 2 & \multirow{4}{*}{0.985} \\
\hline G1 & 16 & 16 & 14 & 14 & 14 & 14 & \\
\hline G2 & 39 & 39 & 43 & 43 & 44 & 44 & \\
\hline G3 & 43 & 43 & 42 & 42 & 40 & 40 & \\
\hline
\end{tabular}

- Unmarried pregnancies were only $2 \%$ in the three groups.

- Primigravida were about $15 \%$ in the three groups, whereas parous women were about $82 \%$.

- $\quad$ Above $86 \%$ of the women belonged to socioeconomic status class IV/V.

- Only $3 \%$ of the women belonged to class I/II socioeconomic status.

- In class III socio-economic status group, there were about $12 \%$ of women.

- $73 \%$ of the patients belonged to $10-12$ weeks gestational age group.

- $19 \%$ of the patients were in the gestational age group of 7 - 9 weeks.

- Only $8 \%$ of the women belonged to less than 7 weeks gestational age group.

\begin{tabular}{|c|c|c|c|c|}
\hline \multicolumn{2}{|c|}{ Characters } & \begin{tabular}{|c|} 
Misoprostol \\
$200 \mu \mathrm{g}$ \\
\end{tabular} & \begin{tabular}{|c|} 
Misoprostol \\
$400 \mu \mathrm{g}$ \\
\end{tabular} & $\begin{array}{c}\text { Misoprostol } \\
600 \mu \mathrm{g} \\
\end{array}$ \\
\hline \multirow{4}{*}{ Parity } & UMP & 24.00 & 22.30 & 18.00 \\
\hline & G1 & 23.20 & 20.00 & 17.00 \\
\hline & G2 & 22.30 & 20.00 & 16.30 \\
\hline & G3 & 22.00 & 19.30 & 16.30 \\
\hline \multirow{3}{*}{$\begin{array}{c}\text { Gestational } \\
\text { Age }\end{array}$} & $<7$ weeks & 24 & 22.30 & 21.30 \\
\hline & $\begin{array}{c}7-9 \\
\text { weeks }\end{array}$ & 22.45 & 21.00 & 17.30 \\
\hline & $\begin{array}{l}10-12 \\
\text { weeks }\end{array}$ & 22.00 & 19.30 & 16.00 \\
\hline
\end{tabular}

UMP- Unmarried pregnancies

- The I-A interval was lowest if the GA was 10 - 12 weeks irrespective of the parity.

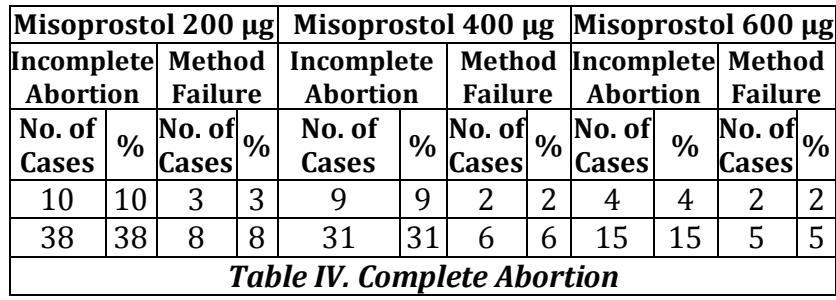

- Complete abortion occurred in $41 \%$ of cases in 200 micrograms group and in $52 \%$ of cases in 400 micrograms group.

- $\quad$ Complete abortion was higher in 600 micrograms group. It occurred in $74 \%$ of cases.

\begin{tabular}{|c|c|c|c|c|c|c|}
\hline \multirow{2}{*}{ Side Effects } & \multicolumn{2}{|c|}{$\begin{array}{c}\text { Misoprostol } \\
\mathbf{2 0 0} \boldsymbol{\mu g}\end{array}$} & \multicolumn{2}{c|}{$\begin{array}{c}\text { Misoprostol } \\
\mathbf{4 0 0} \boldsymbol{\mu g}\end{array}$} & $\begin{array}{c}\text { Misoprostol } \\
\mathbf{6 0 0} \boldsymbol{\mu g}\end{array}$ \\
\cline { 2 - 7 } & $\begin{array}{c}\text { No. of } \\
\text { Cases }\end{array}$ & $\%$ & $\begin{array}{c}\text { No. of } \\
\text { Cases }\end{array}$ & $\%$ & $\begin{array}{c}\text { No. of } \\
\text { Cases }\end{array}$ & $\%$ \\
\hline Symptom Free & 28 & 28 & 19 & 19 & 10 & 10 \\
\hline Vomiting & 27 & 27 & 35 & 35 & 41 & 41 \\
\hline
\end{tabular}

\begin{tabular}{|c|c|c|c|c|c|c|}
\hline Diarrhoea & 1 & 1 & 2 & 2 & 5 & 5 \\
\hline $\begin{array}{c}\text { Abdominal/ } \\
\text { Uterine Cramps }\end{array}$ & 18 & 18 & 18 & 18 & 16 & 16 \\
\hline $\begin{array}{c}\text { Excessive } \\
\text { Bleeding }\end{array}$ & 26 & 26 & 25 & 25 & 26 & 26 \\
\hline Dizziness & 0 & 0 & 1 & 1 & 2 & 2 \\
\hline \multicolumn{7}{|c|}{ Table V. Side Effects }
\end{tabular}

- Symptoms were less with 200 micrograms group.

- Vomiting was higher in 600 micrograms group (41\%), whereas it was noted only in $27 \%$ of cases in micrograms group.

- Only one case had diarrhoea in 200 micrograms group. $2 \%$ in 400 micrograms group and 5\% in 600 micrograms group had diarrhoea.

- Onset of abdominal/ uterine cramps and excessive bleeding were almost similar in all three groups.

- None of them in 200 micrograms group had dizziness.

- Only $1 \%$ in 400 micrograms group and $2 \%$ in 600 micrograms group had dizziness.

Statistical Analysis of Results

\begin{tabular}{|c|c|c|c|c|}
\hline $\begin{array}{c}\text { Dose in } \\
\text { Micrograms }\end{array}$ & N & Mean & $\begin{array}{c}\text { Standard } \\
\text { Deviation }\end{array}$ & P value \\
\hline 200 & 41 & 22.22 & .613 & \multirow{2}{*}{$<0.0001$} \\
\hline 400 & 52 & 19.57 & .936 & \\
\hline 600 & 74 & 16.59 & 2.024 & \\
\hline
\end{tabular}

Table VI. Analysis of Induction-Abortion Interval in Hours

N- No. of complete abortion

- The mean induction-abortion interval in $200 \mu \mathrm{g}, 400 \mu \mathrm{g}$ and $600 \mu$ group is 22.22 hours, 19.57 hours and 16.59 hours respectively.

- $\quad$ By ANOVA with post hoc test (Analysis of Variance), there is a significant difference in induction/abortion interval between the three different groups and within the groups and $\mathrm{p}$ value is $<0.0001$.

\begin{tabular}{|c|c|c|c|c|}
\hline $\begin{array}{c}\text { Gestational } \\
\text { Age }\end{array}$ & Group 1 & Group 2 & Group 3 & \multirow{2}{*}{ P value } \\
\cline { 2 - 4 } & Mean \pm S.D & Mean \pm S.D & Mean \pm S.D & \\
\hline$<7$ weeks & $23.94 \pm 1.19$ & $23.66 \pm 1.98$ & $22.36 \pm 2.05$ & 0.157 \\
\hline $7-9$ weeks & $23.59 \pm 1.81$ & $22.39 \pm 1.89$ & $18.50 \pm 2.84$ & $<0.0001$ \\
\hline $10-12$ weeks & $22.38 \pm 1.01$ & $19.79 \pm 1.30$ & $16.64 \pm 2.63$ & $<0.0001$ \\
\hline P value & $<0.0001$ & $<0.0001$ & $<0.0001$ & \\
\hline Table VII. Analysis of Induction-Abortion Interval in \\
Gestational Age \\
\hline
\end{tabular}

\begin{tabular}{|c|c|c|c|c|}
\hline $\begin{array}{c}\text { Gestational } \\
\text { Age }\end{array}$ & Group 1 & Group 2 & Group 3 & \multirow{2}{*}{ P value } \\
\cline { 2 - 5 } & Mean \pm S.D & Mean \pm S.D & Mean \pm S.D & \\
\hline UMP & $18.65 \pm 1.90$ & $14.00 \pm 0$ & $16.65 \pm 1.90$ & 0.332 \\
\hline G1 & $16.79 \pm 3.15$ & $21.24 \pm 2.25$ & $18.42 \pm 4.25$ & 0.003 \\
\hline G2 & $16.92 \pm 3.21$ & $20.40 \pm 2.55$ & $16.92 \pm 3.21$ & $<0.0001$ \\
\hline G3 & $22.17 \pm 0.99$ & $20.10 \pm 1.72$ & $17.25 \pm 2.88$ & $<0.0001$ \\
\hline P value & $<0.0001$ & 0.014 & 0.565 & \\
\hline \multicolumn{5}{|c|}{ Table VIII. Analysis of Induction-Abortion Interval in } \\
Parity \\
\hline
\end{tabular}

UMP- Unmarried pregnancies

\begin{tabular}{|c|c|c|c|}
\hline & $\begin{array}{c}\text { Complete } \\
\text { Abortion }\end{array}$ & $\begin{array}{c}\text { Incomplete } \\
\text { Abortion }\end{array}$ & P value \\
\hline Misoprostol $200 \mu \mathrm{g}$ & 41 & 48 & \\
\cline { 1 - 3 } Misoprostol $400 \mu \mathrm{g}$ & 52 & 40 & $<0.0001$ \\
\cline { 1 - 3 } Misoprostol $600 \mu \mathrm{g}$ & 74 & 19 & \\
\hline \multicolumn{4}{|l|}{ Table IX. Analysis of Complete/Incomplete Abortion } \\
\hline
\end{tabular}


Statistical analysis shows there is a significant difference in success rate of complete abortion between the three regimens of misoprostol and p-value is 0.01 .

There is statistically significant difference in incomplete abortion between the three regimens with a p-value of 0.05 .

\begin{tabular}{|c|c|c|c|c|c|}
\hline Side Effects & $\begin{array}{c}\text { Vomit- } \\
\text { ing }\end{array}$ & $\begin{array}{c}\text { Diar- } \\
\text { rhoea }\end{array}$ & $\begin{array}{c}\text { Abdominal } \\
\text { Uterine } \\
\text { Cramps }\end{array}$ & $\begin{array}{c}\text { Excessive } \\
\text { Bleeding }\end{array}$ & Dizziness \\
\hline $\begin{array}{c}\text { Misoprostol } \\
200 \mu \mathrm{g}\end{array}$ & 27 & 1 & 18 & 26 & 0 \\
\hline $\begin{array}{c}\text { Misoprostol } \\
400 \mu \mathrm{g}\end{array}$ & 35 & 2 & 18 & 25 & 1 \\
\hline $\begin{array}{c}\text { Misoprostol } \\
600 \mu \mathrm{g}\end{array}$ & 41 & 5 & 16 & 26 & 2 \\
\hline P value & 0.112 & 0.188 & $<0.0001$ & 0.342 & $<0.0001$ \\
\hline \multicolumn{7}{|c|}{ Table X. Statistical Analysis of Side Effects } \\
\hline \multicolumn{7}{|c|}{} \\
\hline
\end{tabular}

By statistical analysis (Correlation) of side effects of the drug revealed the following results- $16.8 \%$ symptom free, $41.9 \%$ vomiting, $19.2 \%$ abdominal/uterine cramps, $18.6 \%$ excessive bleeding, $2.4 \%$ diarrhoea and $1.2 \%$ dizziness.

Among the three dosage groups there is statistically significant difference in the incidence of side effects, vomiting $[6 \%, 15.6 \%, 20.4 \%]$, diarrhoea $[0.0 \%, 0.6 \%, 1.8 \%]$, abdominal/uterine cramps $(7.8 \%, 6.0 \%, 5.4 \%)$, excessive bleeding $(3.0 \%, 4.2 \%, 11.4 \%)$, dizziness $(0.0 \%, 0.6 \%, 0.6 \%)$ between 200, 400 and $600 \mu \mathrm{g}$ respectively.

\section{DISCUSSION}

This study comparing the efficacy of three different regimens of vaginal misoprostol in the termination of first trimester of pregnancy was undertaken in 300 patients.

\section{The Results of this study were discussed as follows-}

Table I: $78 \%$ of the patients were in the age group of $21-30$ years.

Table II: $82 \%$ of cases were parous women, whereas only $18 \%$ of cases were nullipara.

Table III: Above $85 \%$ of the women in this study belonged to class IV/ V socioeconomic status.

Table IV: Though patients were selected at random, 73\% of patients were 10 - 12 weeks pregnant.

Table V: In this study induction-abortion interval was less with 600 micrograms of misoprostol. The I-A interval was least when the GA was 10 - 12 weeks.

Table VI: In this study complete abortion occurred in $41 \%$, $52 \%$ and $74 \%$ of cases in 200 micrograms, 400 micrograms and 600 micrograms groups respectively. The success rates were different in different studies using different route of administration and doses. A study by Koopersmith and Mishell 1996 showed the success rate of $50 \%$ when 200 micrograms was used and $60 \%$ when the dose was 400 micrograms. $4,5,6,7$ Success rate of $81 \%$ of complete abortion with 800 ug [Esteve JL et al 1998] at 24 hours interval.8,9,10,11 Success rate is $97 \%$ complete abortion using 800 micrograms at 24 hours interval (Jain, Mekstrath, Lacarrt 1998). 84\% of complete abortion occurred when 800 micrograms were used at 24 hours interval by Carbonell et al 2001.12,13,14,15 Ngai et al showed success rate of $85 \%$ complete abortion using 800 micrograms of misoprostol at 48 hours interval.

Table VII: In this study, $27 \%$ of women in the 200 micrograms group had vomiting. Other side effects reported were uterine/abdominal cramps (18\%), excessive bleeding $(26 \%)$ and diarrhoea (1\%). Study by Bugalho et al reported nausea (19\%), vomiting (6\%), diarrhoea (7\%), fatigue $(12 \%)$ and lower abdominal pain (71\%). ${ }^{16,17,18}$ In this study 400 micrograms group women experienced the following side effects, viz. vomiting (35\%), excessive bleeding (25\%), abdominal cramps (18\%), diarrhoea (2\%) and dizziness (1\%). When compared to other two groups $41 \%$ of women in 600 micrograms group experienced vomiting, 16\% uterine cramps, $5 \%$ diarrhoea and $2 \%$ dizziness. Various studies conducted by Carbonell et al [1999 - 2000] using different doses at different intervals showed varying side effects. 19,20,21

Nausea (22\%), vomiting (17\%), diarrhoea (54\%), dizziness $(25 \%)$, headache $(19 \%)$, fever $(26 \%)$, pelvic pain (99\%) experienced by women using 800 micrograms misoprostol (Carbonell, Fernandez C, et al 1998).22,23,24,25

Table VIII: Mean induction-abortion interval in $200 \mathrm{ug}, 400$ ug and 600 ug is 22.22, 19.57 and 16.59 respectively. Maximum interval is 24, 22 and 21 respectively. Bebbington, Michael W et al AJOG reported that induction-abortion interval with the vaginal route was less (24 hours) $26,27,28$ when compared with oral route with a statistically significant difference of 0.01 . Study by F Dong et al (BJOG) using $800 \mu \mathrm{g}$ of vaginal misoprostol reported that the mean interval between first dose of misoprostol and the onset of expulsion of products of conception (SD) as 8.1 hours. ${ }^{29,30,31}$

Table IX: There is a statistically significant difference in I-A Interval between the three dosage groups and $\mathrm{p}$ value of 0.000 .

Table X: Difference in I-A interval between the three gestational age groups is statistically significant and p-value is 0.027 . Surg. Capt. Sushil Kumar et al reported success rate of $67 \%$ using $800 \mu \mathrm{g}$ vaginal misoprostol at $<8$ weeks and $83 \%$ at $8-12$ weeks. ${ }^{32,33}$

Table XI: There is no statistically significant difference in I-A interval in parity and p-value of 0.233 .

Table XII: There is statistically significant difference in success rate of complete and incomplete abortions with a pvalue of 0.01 and 0.05 . A WHO multicentric trial (19982000) using three misoprostol regimens after pre-treatment with mifepristone showed success rate of $96-98 \%$ in all the groups.

Table XIII: Statistically significant difference is observed in incidence of side effects in the three dosage groups. Hamoda, Ashok et al, AJOG reported nausea $p=.008)$, diarrhoea $(\mathrm{p}=0.01)$ and unpleasant mouth taste $(\mathrm{p}=0.0001)$ in sublingual group compared with women in the vaginal route.34,35 In a study by Mittal, Kumar et al more women experienced vaginal bleeding, abdominal pain and shivering in the $400 \mu \mathrm{g}$ misoprostol group compared with the $200 \mathrm{ug}$ 
misoprostol group with a statistically significant difference $(\mathrm{p}<0.05)$.

\section{Summary}

This present randomised controlled study conducted at Government Kasturba Gandhi Hospital for Women and Children, Chennai during the period 2004 - 2006 evaluated the efficacy of the three regimens of vaginal misoprostol in the termination of first trimester of pregnancy.

A total of 300 women who attended the family planning clinic requesting for first trimester termination of pregnancy were included in the study.

The efficacy of three regimens of vaginal misoprostol was compared in terms of Induction-Abortion interval, complete abortion, incomplete abortion and incidence of side effects and the results were statistically analysed. Observations in this study include-

- $\quad$ Most of the patients were in the age group of 21 - 30 years $(78 \%)$.

- $82 \%$ of the women were parous, only $18 \%$ were nullipara.

- Most of the women belonged to class IV/V socioeconomic status (85\%).

- $73 \%$ of the patients belonged to 10 - 12 weeks of gestation, though they were selected at random basis.

- In the study, I-A interval was less (16.30 hours) with 600 micrograms.

- Complete abortion varied in the three groups and was highest in 600 micrograms group (74\%).

- $\quad$ Side effects were less in women who received 200 ug. None of the women in this group had dizziness and only one patient had diarrhoea. Incidence of bleeding was similar in all the three groups.

- Mean I-A interval using 200 micrograms was 22.22 hours with 400 micrograms it was 19.57 hours and with 600 micrograms 16.59 hours.

- Statistically, there is a significant difference in I-A interval between and within the three dosage groups $(\mathrm{p}=$ 0.000 )

- There is also a statistically significant difference in I-A interval between and within the gestational age groups $(\mathrm{p}=0.027)$.

- There is no significant difference in I-A interval between and within the parity by statistical analysis.

- Statistically significant difference is there in complete and incomplete abortion between the three regimens. $(\mathrm{p}=0.01$ and 0.05$)$.

- Statistically, there is significant difference in the incidence of side effects with the three regimens.

\section{CONCLUSION}

- Induction-Abortion interval is less with $600 \mu \mathrm{g}$ when compared to $400 \mu \mathrm{g}$ and $200 \mu \mathrm{g}$.

- Induction-Abortion interval in 10 - 12 weeks of gestation observed in this is less.

- Complete abortion rate was more with $600 \mu$ g regimen when compared to other two regimens.

- Incidence of side effects was less with $200 \mu \mathrm{g}$.

- There was almost similar incidence of abdominal/ uterine cramps and excessive bleeding.
Medical management of MTP is a boon to low resource countries like India, where infrastructural facilities and trained personnel are at a premium. However, there is scope for misuse of this drug, which needs to be curtailed and watched. This is a comparatively inexpensive, easy to administer technique, which when used by properly trained persons, in a setup with facilities for further management as and when required, will go a long way in reducing the unwanted interferences by unscrupulous persons.

\section{REFERENCES}

[1] Ayres-de-Campos D, Teixeira-da-Silva J, Campos I, et al. Vaginal misoprostol in the management of firsttrimester missed abortions. Int J Gynaecol Obstet 2000;71(1):53-7.

[2] Bugalho A, Bique C, Almeida L, et al. Pregnancy interruption by vaginal misoprostol. Gynecol Obstet Invest 1993;36(4):226-9.

[3] Carbonell JL, Varela L, Velazco A, et al. The use of misoprostol for abortion at $<$ or $=9$ weeks gestation. Eur J Contracept Reprod Health Care 1973;2(3):181-5.

[4] Carbonell JL, Varela L, Velazco A, et al. The use of misoprostol for termination of early pregnancy. Contraception 1997;55(3):165-8.

[5] Carbonell JL, Varela L, Velazco A, et al. Vaginal misoprostol for late first trimester abortion. Contraception 1998;57(5):329-33.

[6] Carbonell JL, Varela L, Velazco A, et al. Vaginal misoprostol for early second trimester abortion. Eur J Contracept Reprod Health Care 1998;3(2):93-8.

[7] Carbonell JL, Varela L, Velazco A, et al. Vaginal misoprostol for abortion at 10-13 weeks' gestation. Eur J Contracept Reprod Health Care 1999;4(1):35-40.

[8] Carbonell JL, Varela L, Velazco A, et al. Vaginal misoprostol $600 \mu \mathrm{g}$ for early abortion. Eur J Contracept Reprod Health Care 2000;5(1):46-51.

[9] Carbonell JL, Rodriquez J, Aragon S, et al. Vaginal misoprostol 1000 microg for early abortion. Contraception 2001;63(3):131-6.

[10] Carbonell JL, Velazco A, Varela L, et al. Misoprostol for abortion at $9-12$ weeks' gestation in adolescents. Eur J Contracept Reprod Health Care 2001;6(1):39-45.

[11] Gonzalez CH, Marques-Dias MJ, Kim CA, et al. Congenital abnormalities in Brazilian children associated with misoprostol misuse in first trimester of pregnancy. Lancet 1998;351(9116)1624-7.

[12] Faundes A, Santos LC, Carvalho M, et al. Post-abortion complication of pregnancy with misoprostol Adv Contracept 1996;12(1):1-9.

[13] Haberal A, Celikkanat H, Batioglu S. Oral misoprostol use in early complicated pregnancy. Adv Contracept 1996;12(2):139-43.

[14] el-Refaey H, O'Brien P, Morafa W, et al. Use of oral misoprostol in the prevention of postpartum haemorrhage. Br J Obstet Gynaecol 1997;104(3): 336-9.

[15] Winikoff B, Ellertson C, Clark S. Analysis of failure in medical abortion. Contraception 1996;54(6):323-7.

[16] Creinin MD, Vittinghoff E. Methorrexate and misoprostol vs. misoprostol alone for early abortion: a randomized controlled trial. J Am Med Assoc 1994;272(15):1190-5. 
[17] Jain JK, Mishell DR, Mekstroth K, et al. The use of vaginal misoprostol for termination of pregnancies $<56$ days [abstract]. American Public Health Association 126th Annual Meeting, Washington, DC. November 15-18, 1998.

[18] Koopersmith TB, Mishell DR. The use of misoprostol for termination of early pregnancy. Contraception 1996;53(4):238-42.

[19] Ngai SW, Tang OS, Chan YM, et al. Vaginal misoprostol alone for medical abortion up to 9 weeks of gestation: efficacy and acceptability. Human Reprod 2000;15(5):1159-62.

[20] Norman JE, Thong K], Baird DT. Uterine contractility and induction of abortion in early pregnancy by misoprostol and mifepristone. Lancet 1991;338(8777):1233-6.

[21] Tang OS, Miao BY, Le SW, et al. Pilot study on the use of repeated doses of sublingual misoprostol in termination of pregnancy up to 12 weeks gestation: efficacy and acceptability. Hum Reprod 2002;17(3):654-8.

[22] Government of India: Ministry of Health and Family Welfare Annual Report 2003 -2004.

[23] Ashok PW, Hamoda H, Nathani F, et al. Randomised controlled study comparing oral and vaginal misoprostol for cervical priming prior to surgical termination of pregnancy. BJOG 2003;110(12):105761.

[24] Ekerhovd E, Radulovic N, Norstrom A. Gemeprost versus misoprostol for cervical priming before firsttrimester abortion: a randomized controlled trial. Obstet Gynecol 2003;101(4):722-5.

[25] Spitz IM, Bardin CW, Benton L, et al. Early pregnancy termination with mifepristone and misoprostol in the United States. N Engl J Med 1998;338(18):1241-7.
[26] Peyron R, Aubeny E, Targosz V, et al. Early termination of pregnancy with mifepristone (RU 486) and the orally active prostaglandin misoprostol. N Engl J Med 1993;328(21):1509-13.

[27] Schaff EA, Fielding SL, Eisinger SH, et al. Low-dose mifepristone followed by vaginal misoprostol at 48 hours for abortion up to 63 days. Contraception 2000;61(1):41-6.

[28] Wiebe E, Dunn S, Guilbert E, et al. Comparison of abortions induced by methotrexate or mifepristone followed by misoprostol. Obstet Gynecol 2002;99(5 Pt 1):813-9.

[29] Kruse B, Poppema S, Creinin MD, et al. Management of side effects and complications in medical abortion. Am J Obstet Gynecol 2000;183(2 Suppl):S65-75.

[30] Tang OS, Wong KS, Tang LCH, et al. Pilot study on the use of repeated doses of misoprostol in termination of pregnancy at less than 9 weeks of gestation. Adv Contracept 1999;15(3):211-6.

[31] Billings DL. Misoprostol alone for early medical abortion in a Latin American clinic setting. Reprod Health Matters 2004;12(24 Suppl):57-64.

[32] Blanchard K, Shochet T, Coyaji K, et al. Misoprostol alone for early abortion: an evaluation of seven potential regimens. Contraception 2005;72(2):91-7.

[33] Ekmekcioglu, Demirci, Yilmaz, et al. Intraurethral misoprostol: a different agent in the treatment of erectile dysfunction. Sexual Dysfunction 1998;1(3):161-4.

[34] Barbosa RM, Arilha M. The Brazilian experience with cytotec. Stud Fam Plan 1993;24(4);236-40.

[35] Singh K, Fong YF, Dong F. A viable alternative to surgical vacuum aspiration: repeated doses of intravaginal misoprostol over 9 hours for medical termination of pregnancies up to eight weeks. BJOG 2003;110(2):175-80. 